\title{
Article \\ Synthesis, Crystal Structure and Magnetic Properties of 1D Chain Complexes Based on Azo Carboxylate Oxime Ligand
}

\author{
Min Zeng, Xi Chen ${ }^{\dagger}$ and Hui-Zhong Kou *D \\ Department of Chemistry, Tsinghua University, Beijing 100084, China; zengmin@mail.tsinghua.edu.cn \\ * Correspondence: kouhz@mail.tsinghua.edu.cn \\ + Deceased.
}

check for

updates

Citation: Zeng, M.; Chen, X.; Kou, H.-Z. Synthesis, Crystal Structure and Magnetic Properties of 1D Chain

Complexes Based on Azo

Carboxylate Oxime Ligand. Magnetochemistry 2021, 7, 105. https://doi.org/10.3390 /magnetochemistry7070105

Academic Editors: Zhao-Yang Li, Ryuta Ishikawa and Yoji Horii

Received: 22 June 2021

Accepted: 12 July 2021

Published: 14 July 2021

Publisher's Note: MDPI stays neutral with regard to jurisdictional claims in published maps and institutional affiliations.

Copyright: (c) 2021 by the authors. Licensee MDPI, Basel, Switzerland. This article is an open access article distributed under the terms and conditions of the Creative Commons Attribution (CC BY) license (https:/ / creativecommons.org/licenses/by/ $4.0 /)$.
Abstract: Two carboxylate-bridged one-dimensional chain complexes, $\left\{\left[\mathrm{Mn}^{\mathrm{II}}(\mathrm{MeOH})_{2}\right]\left[\mathrm{Fe}^{\mathrm{III}}(\mathrm{L})_{2}\right]_{2}\right\}_{n}$ (1) and $\left\{\left[\mathrm{Mn}^{\mathrm{II}}(\mathrm{DMF})_{2}\right]\left[\mathrm{Mn}^{\mathrm{III}}(\mathrm{L})_{2}\right]_{2} \cdot \mathrm{DMF}\right\}_{\mathrm{n}}(2)\left[\mathrm{H}_{2} \mathrm{~L}=((2\right.$-carboxyphenyl)azo)-benzaldoxime $]$, containing a low-spin $\left[\mathrm{Fe}^{\mathrm{III}}(\mathrm{L})_{2}\right]^{-}$or $\left[\mathrm{Mn}^{\mathrm{III}}(\mathrm{L})_{2}\right]^{-}$unit were synthesized. Magnetic measurements show that the adjacent high-spin $\mathrm{Mn}^{\mathrm{II}}$ and low-spin $\mathrm{M}^{\mathrm{III}}$ ions display weak antiferromagnetic coupling via the syn-anti carboxyl bridges, with $J=-0.066(2) \mathrm{cm}^{-1}$ for complex 1 and $J=-0.274(2) \mathrm{cm}^{-1}$ for complex 2.

Keywords: one-dimensional complex; low spin; antiferromagnetic coupling; Mn(III); Fe(III)

\section{Introduction}

Low-spin (LS) $\mathrm{M}^{\mathrm{III}}(\mathrm{M}=\mathrm{Fe}$ or $\mathrm{Mn}$ ) ions have been widely used for assembling lowdimensional molecular magnets [1-6], owing to the magnetic anisotropy and spin-orbit coupling for $\mathrm{LS} \mathrm{M}^{\mathrm{III}}$ (M = Fe or Mn) ions, as well as zero-field splitting (ZFS) for LS Mn ${ }^{\mathrm{III}}$ [6]. Moreover, LS $\mathrm{M}^{\mathrm{III}}$-based hetero-bimetallic complexes would exhibit a high-spin ground state due to ferromagnetic coupling between LS $\mathrm{M}^{\mathrm{III}}$ and $\mathrm{M}^{\mathrm{III}}$ (e.g., $\mathrm{Ni}, \mathrm{Cu}$ ) according to the rule of strict orbital orthogonality ( $\mathrm{t}_{2 \mathrm{~g}} \mathrm{vs}$. $\mathrm{e}_{\mathrm{g}}$ ) [7]. According to the crystal-field theory for coordination compounds, LS $\mathrm{M}^{\mathrm{III}}$ should be surrounded by strong-field ligands. Nevertheless, stable LS $\mathrm{M}^{\mathrm{III}}$-containing building blocks are still limited, most of which are cyanide complexes $[2-5,8-13]$. The search for suitable strong-field ligands can help to obtain new LS M ${ }^{\mathrm{III}}$-containing complexes.

Carboxylate ligands possessing a variety of bridging modes, such as syn-syn, synanti, and anti-anti, play an important role in magnetic coupling propagation $[14,15]$. Azo carboxylate oxime ligands have emerged and contributed to the formation of stable LS M $\mathrm{M}^{\mathrm{III}}(\mathrm{L})_{2}$ building units [16-18]. However, the valence of metal ions is also strongly related to the self-assembly processes of the complexes. According to our previous report, under one-pot reaction, $\mathrm{Mn}^{\mathrm{IV}}(\mathrm{L})_{2}$ was formed in which aromatic azo oxime ligand $\mathrm{H}_{2} \mathrm{~L}$ acts as an (L.) $)^{3-}$ radical to stabilize $\mathrm{Mn}^{\mathrm{IV}}$ [19]. In this paper, a complex-as-ligand method is used to obtain carboxylate-bridged $\mathrm{M}^{\mathrm{III}} \mathrm{Mn}^{\mathrm{II}}$ complexes. The precursor LS M(III) complexes are $\mathrm{Et}_{4} \mathrm{~N}\left[\mathrm{M}^{\mathrm{III}}(\mathrm{L})_{2}\right](\mathrm{M}=\mathrm{Fe}$ or $\mathrm{Mn})[16,17]$. The reaction of $\mathrm{Et}_{4} \mathrm{~N}\left[\mathrm{M}^{\mathrm{III}}(\mathrm{L})_{2}\right]$ with $\mathrm{Mn}(\mathrm{OAc})_{2}$ gives rise to two novel one-dimensional complexes $\left\{\left[\mathrm{Mn}^{\mathrm{II}}(\mathrm{MeOH})_{2}\right]\left[\mathrm{Fe}^{\mathrm{III}}(\mathrm{L})_{2}\right]_{2}\right\}_{n}$ (1) and $\left\{\left[\mathrm{Mn}^{\mathrm{II}}(\mathrm{DMF})_{2}\right]\left[\mathrm{Mn}^{\mathrm{III}}(\mathrm{L})_{2}\right]_{2} \cdot \mathrm{DMF}\right\}_{\mathrm{n}}(2)$ based on the azo carboxylate oxime ligand ((2-carboxyphenyl)azo)-benzaldoxime $\left(\mathrm{H}_{2} \mathrm{~L}\right.$, Scheme 1$)$. Magnetic susceptibility measurements show that the intrachain antiferromagnetic coupling exists between adjacent the $\mathrm{M}^{\mathrm{III}}$ and $\mathrm{Mn}^{\mathrm{II}}$ via the syn-anti carboxylate bridges. 

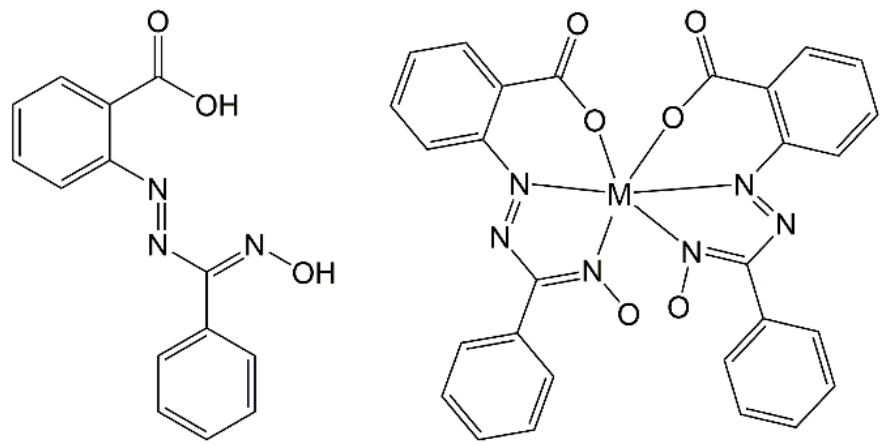

Scheme 1. Molecular structure of $\mathrm{H}_{2} \mathrm{~L}$ and $\left[\mathrm{M}(\mathrm{L})_{2}\right]^{-}(\mathrm{M}=\mathrm{Fe}$ or $\mathrm{Mn})$.

\section{Results}

Complexes 1 and 2 were obtained by a two-step method. Firstly, the complex $\mathrm{Et}_{4} \mathrm{~N}\left[\mathrm{M}(\mathrm{L})_{2}\right](\mathrm{M}=\mathrm{Fe}$ or $\mathrm{Mn})$ was synthesized by the coordination of $\mathrm{H}_{2} \mathrm{~L}$ and metal ion; Secondly, the obtained complex is acted as a ligand to further coordinate with the second metal ion through the carboxyl group to form the target complexes $\left\{\left[\mathrm{Mn}^{\mathrm{II}}(\mathrm{MeOH})_{2}\right]\left[\mathrm{Fe}^{\mathrm{III}}(\mathrm{L})_{2}\right]_{2}\right\}_{n}$ (1) and $\left\{\left[\mathrm{Mn}^{\mathrm{II}}(\mathrm{DMF})_{2}\right]\left[\mathrm{Mn}^{\mathrm{III}}(\mathrm{L})_{2}\right]_{2} \cdot \mathrm{DMF}\right\}_{n}$ (2). Powder X-ray diffraction (PXRD) patterns of complexes 1 and 2 are in good agreement with those simulated by Mercury software (Figure S1), indicating that the obtained crystals have high phase purity.

\subsection{Crystal Structures}

The crystallographic parameters for 1-2 are listed in Table 1 . Complex 1 crystallizes in the tetragonal space group $\mathrm{P} 4(2) / \mathrm{n}$ and complex 2 crystallizes in the triclinic space group P-1. The bond lengths for the $\left[\mathrm{M}(\mathrm{L})_{2}\right]^{-}$are displayed in Table 2. Complexes 1 and 2 have a similar alternating $-\mathrm{Mn}^{\mathrm{II}}-\left[\mathrm{M}^{\mathrm{III}}(\mathrm{L})_{2}\right]^{-}(\mathrm{M}=\mathrm{Mn}$ or $\mathrm{Fe}) 1 \mathrm{D}$ chain structure with a neutral structural unit consisting of two $\left[\mathrm{M}^{\mathrm{III}}\left(\mathrm{L}_{2}\right]^{-}\right.$and one $\mathrm{Mn}^{\mathrm{II}}$ (Figures 1 and 2 and Figures S2 and S3). The intrachain $\mathrm{Mn}^{\mathrm{II}}-\mathrm{M}^{\mathrm{III}}$ separations are 5.454(1) $\AA$ for complex 1 and 5.990(1) $\AA$ for complex 2, respectively. The $\mathrm{Mn}^{\mathrm{II}}$ ion occupies the center of the structure with four $\left[\mathrm{M}^{\mathrm{III}}(\mathrm{L})_{2}\right]^{-}$groups connected on opposite sides by carboxylate bridges in the syn-anti mode. Two coordinating $\mathrm{MeOH}$ or DMF oxygen atoms are situated at the axial coordination sites to form an octahedral $\mathrm{MnO}_{6}$ coordination sphere. The corresponding Mn1-O and Mn2-O bond lengths in complexes 1 and 2 are within the range of 2.151(3)-2.193(2) (Table 3), all above $2 \AA$, typical of the +2 oxidation state of HS Mn ions, which is further confirmed by the bond valence sum (BVS) calculation (Supplementary Materials, Table S1). The coordination geometry of $\mathrm{Mn}^{\mathrm{II}}$ ion in complexes 1 and 2 calculated by the SHAPE [20] software approaches $\mathrm{O}_{\mathrm{h}}$, with the smallest deviation value of 1.459 and 0.085 , respectively (Table S2). The presence of crystallographic disorder in the coordinating methanol molecules makes the calculated deviation value for complex 1 large, and therefore the deviation value of 1.459 should be treated with care. The difference between these two complexes is that the two $\left[\mathrm{Fe}^{\mathrm{III}}(\mathrm{L})_{2}\right]^{-}$units at the opposite sides of Mn(II) are orthogonal to each other in complex 1 , while the two $\left[\mathrm{Mn}^{\mathrm{III}}(\mathrm{L})_{2}\right]^{-}$units in complex 2 are coplanar. The coordination geometry of $\mathrm{Fe}^{\mathrm{III}}$ ions in $\left[\mathrm{Fe}^{\mathrm{III}}(\mathrm{L})_{2}\right]^{-}$and $\mathrm{Mn}^{\mathrm{III}}$ ions in $\left[\mathrm{Mn}^{\mathrm{III}}(\mathrm{L})_{2}\right]^{-}$is close to $\mathrm{O}_{\mathrm{h}}$ calculated by the SHAPE software, with the smallest deviation values of 0.588 and 0.807 , respectively (Table S2). The calculation results (Table S2) also indicate that the distortion toward trigonal prism $\left(\mathrm{D}_{3 \mathrm{~h}}\right)$ has been found for all metal ions with the second smallest deviation values. 
Table 1. Crystallographic parameters of complexes 1-2.

\begin{tabular}{|c|c|c|}
\hline & 1 & 2 \\
\hline Formula & $\mathrm{C}_{58} \mathrm{H}_{44} \mathrm{Fe}_{2} \mathrm{MnN}_{12} \mathrm{O}_{14}$ & $\mathrm{C}_{65} \mathrm{H}_{57} \mathrm{Mn}_{3} \mathrm{~N}_{15} \mathrm{O}_{15}$ \\
\hline Fw & 1299.69 & 1453.07 \\
\hline $\mathrm{T} / \mathrm{K}$ & $293(2)$ & $293(2)$ \\
\hline Crystal system & Tetragonal & Triclinic \\
\hline Space group & $\mathrm{P} 4(2) / \mathrm{n}$ & P-1 \\
\hline $\mathrm{a} / \AA$ & $20.651(3)$ & $9.2247(6)$ \\
\hline $\mathrm{b} / \AA$ & 20.651(3) & $13.2300(7)$ \\
\hline$c / \AA$ & $13.641(3)$ & $14.2577(8)$ \\
\hline$\alpha /{ }^{\circ}$ & 90 & 82.3377(15) \\
\hline$\beta /{ }^{\circ}$ & 90 & $79.666(2)$ \\
\hline$\gamma /{ }^{\circ}$ & 90 & $85.466(2)$ \\
\hline $\mathrm{V} / \AA^{3}$ & $5818(2)$ & 1693.83(17) \\
\hline Z & 4 & 1 \\
\hline$\rho_{\text {calcd }} / \mathrm{g} \mathrm{cm}^{-1}$ & 1.484 & 1.496 \\
\hline Reflections collected & 6637 & 7655 \\
\hline GOF on $\mathrm{F}^{2}$ & 1.090 & 1.153 \\
\hline $\mathrm{R} 1[\mathrm{I}>2 \sigma(\mathrm{I})]$ & 0.0579 & 0.0485 \\
\hline wR2 (all data) & 0.1972 & 0.1631 \\
\hline CCDC & 2044110 & 2044111 \\
\hline
\end{tabular}

Table 2. Selected bond lengths $(\AA)$ and angles $\left(^{\circ}\right)$ for the $\left[\mathrm{M}(\mathrm{L})_{2}\right]^{-}$in complexes $1-2$ and the previously reported $\mathrm{Et}_{4} \mathrm{~N}\left[\mathrm{M}(\mathrm{L})_{2}\right][16,17]$.

\begin{tabular}{|c|c|c|c|c|}
\hline & $\begin{array}{c}\text { Complex } 1 \\
(\mathrm{M}=\mathrm{Fe})\end{array}$ & $\begin{array}{c}\mathrm{Et}_{4} \mathrm{~N}\left[\mathrm{Fe}(\mathrm{L})_{2}\right] \\
{[16]} \\
(\mathrm{M}=\mathrm{Fe})\end{array}$ & $\begin{array}{c}\text { Complex } 2 \\
(\mathbf{M}=\mathbf{M n})\end{array}$ & $\begin{array}{c}\mathrm{Et}_{4} \mathrm{~N}\left[\mathrm{Mn}(\mathrm{L})_{2}\right] \\
{[17]} \\
(\mathbf{M}=\mathbf{M n})\end{array}$ \\
\hline M1-O1 & $1.935(3)$ & $1.919(6)$ & $1.939(3)$ & $1.906(7)$ \\
\hline M1-O5 & $1.929(2)$ & $1.879(6)$ & $1.929(3)$ & $1.906(7)$ \\
\hline M1-N1 & $1.895(3)$ & $1.892(6)$ & $1.924(3)$ & $1.929(6)$ \\
\hline M1-N3 & $1.887(3)$ & $1.907(6)$ & $1.950(3)$ & $1.950(7)$ \\
\hline M1-N4 & $1.904(3)$ & $1.888(6)$ & $1.934(3)$ & $1.929(6)$ \\
\hline M1-N6 & $1.895(3)$ & $1.899(7)$ & $1.953(3)$ & $1.950(7)$ \\
\hline M1-O5-C15 & $127.8(2)$ & $129.0(3)$ & $131.3(2)$ & $132.7(3)$ \\
\hline M1-O1-C1 & 127.6(2) & $130.3(3)$ & 131.7(2) & 132.7(3) \\
\hline O1-M1-N3 & $172.54(13)$ & $170.7(2)$ & $170.11(12)$ & $168.4(3)$ \\
\hline O5-M1-N6 & $172.36(13)$ & $165.9(3)$ & $170.33(12)$ & $168.4(3)$ \\
\hline N1-M1-N4 & $178.44(13)$ & 178.5(3) & $164.92(12)$ & $173.4(5)$ \\
\hline
\end{tabular}
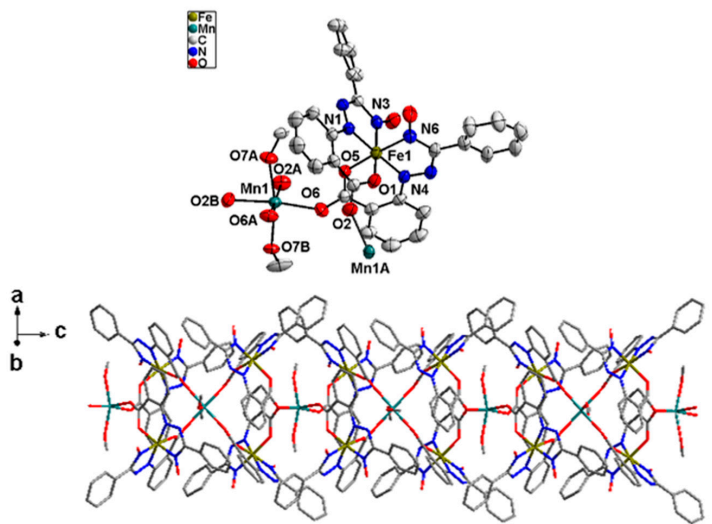

Figure 1. Molecular structure of complex 1. Top: thermal ellipsoids. Bottom: The 1D chain. Hydrogen atoms and solvent molecules are omitted for clarity. Fe: dark yellow; Mn: cyan; C: gray; N: blue; O: red. 

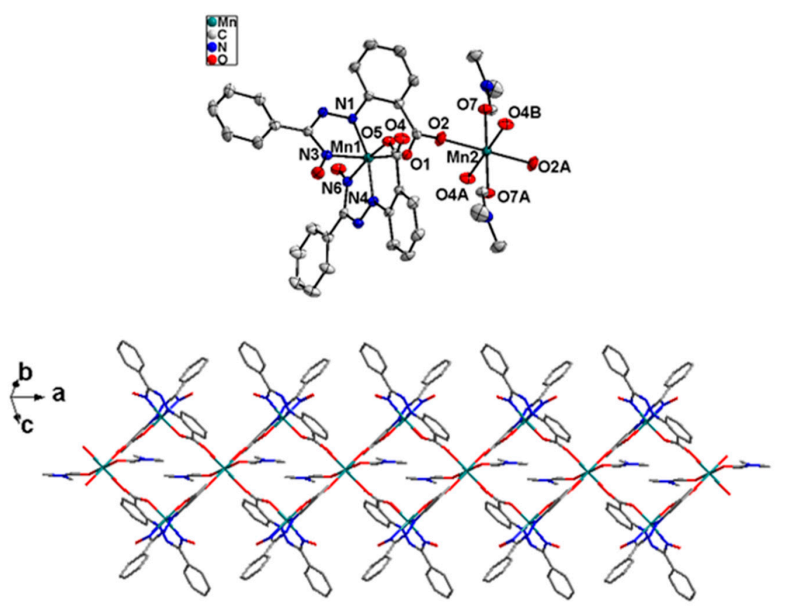

Figure 2. Molecular structure of complex 2. Top: thermal ellipsoids. Bottom: The 1D chain structure. Hydrogen atoms and solvent molecules are omitted for clarity. Mn: cyan; C: gray; N: blue; O: red.

Table 3. Bond length $(\AA)$ and angles $\left(^{\circ}\right)$ of the Mn(II) ions in complexes 1-2.

\begin{tabular}{cccc}
\hline & $\mathbf{1}$ & & $\mathbf{2}$ \\
\hline Mn1-O2A & $2.183(3)$ & Mn2-O2 & $2.151(3)$ \\
Mn1-O2B & $2.183(3)$ & Mn2-O2A & $2.151(3)$ \\
Mn1-O6 & $2.192(3)$ & Mn2-O4 & $2.162(3)$ \\
Mn1-O6A & $2.192(3)$ & Mn2-O4A & $2.162(3)$ \\
Mn1-O7A & $2.181(7)$ & Mn2-O7 & $2.167(3)$ \\
Mn1-O7B & $2.193(5)$ & Mn2-O7A & $2.167(3)$ \\
C1A-O2A-Mn1 & $144.6(3)$ & Mn2-O2-C1 & $167.8(3)$ \\
C15-O6-Mn1 & $139.6(3)$ & Mn2-O4A-C15A & $169.3(3$ \\
O7A-Mn1-O7B & $164.58(25)$ & O2B-Mn1-O6 & $172.65(11)$ \\
\hline
\end{tabular}

For the $\left[\mathrm{Fe}(\mathrm{L})_{2}\right]^{-}$units in complex 1 , the $\mathrm{Fe}-\mathrm{N}$ bond distances are in the range of 1.887(3)-1.904(3) $\AA$, which are similar to those in $\mathrm{Et}_{4} \mathrm{~N}\left[\mathrm{Fe}^{\mathrm{III}}(\mathrm{L})_{2}\right]$ [17]. The $\mathrm{Fe}-\mathrm{O}$ bond distances are 1.929(2) $\AA$ and 1.935(3) $\AA$, a little longer than that (1.919 and $1.879 \AA$ ) in $\mathrm{Et}_{4} \mathrm{~N}\left[\mathrm{Fe}^{\mathrm{III}}(\mathrm{L})_{2}\right]$ (Table 2). A similar situation occurs to the $\left[\mathrm{Mn}(\mathrm{L})_{2}\right]^{-}$units in complex 2: the $\mathrm{Mn}-\mathrm{N}$ bond distances in the range of 1.924(3)-1.953(3) $\AA$ are similar to those in $\mathrm{Et}_{4} \mathrm{~N}\left[\mathrm{Mn}^{\mathrm{III}}(\mathrm{L})_{2}\right][18]$, and the Mn-O bond distances (1.929(3) and 1.939(3) $\AA$ ) are slightly longer. The M-O elongation should be due to the bridging coordination of the carboxylate groups [19]. M-N/O bond lengths for HS Mn(III) ions are generally longer than $2.0 \AA$ owing to the Jahn-Teller distortion. In complex 2, all the Mn-N/O bond lengths in $\left[\mathrm{Mn}(\mathrm{L})_{2}\right]^{-}$ units are shorter than $2 \AA$, indicating that the $\mathrm{Mn}(\mathrm{III})$ ions in $\left[\mathrm{M}(\mathrm{L})_{2}\right]^{-}$units are in LS state with negligible Jahn-Teller effect. This assumption is further confirmed by the BVS calculation and the cyclic voltammetry (Supplementary Materials, Figure S4). The CV curves show nearly reversible redox responses for complexes $1\left(E_{1 / 2}=-0.016 \mathrm{~V}\right.$ vs. SCE $)$ and $2\left(E_{1 / 2}=-0.048 \mathrm{~V}\right.$ vs. SCE), consistent with that of previously reported $\mathrm{Et}_{4} \mathrm{~N}\left[\mathrm{Fe}^{\mathrm{III}}(\mathrm{L})_{2}\right]$ $(-0.05 \mathrm{~V})$ and $\mathrm{Et}_{4} \mathrm{~N}\left[\mathrm{Mn}^{\mathrm{III}}(\mathrm{L})_{2}\right](-0.065 \mathrm{~V})$, and can be attributed to the redox processes $\left[\mathrm{Fe}^{\mathrm{III}}(\mathrm{L})_{2}\right]^{-}+\mathrm{e}^{-} \leftrightharpoons\left[\mathrm{Fe}^{\mathrm{II}}(\mathrm{L})_{2}\right]^{2-}$ and $\left[\mathrm{Mn}^{\mathrm{III}}(\mathrm{L})_{2}\right]^{-}+\mathrm{e}^{-} \leftrightharpoons\left[\mathrm{Mn}^{\mathrm{II}}(\mathrm{L})_{2}\right]^{2-}$, respectively. Thus, complex 1 is a rare example of a carboxylate-bridged $\mathrm{Mn}$ (II)-Fe(III) chain complex, and 2 is a new mixed-valent $\mathrm{Mn}^{\mathrm{II}} \mathrm{Mn}^{\mathrm{III}}$ complex. In complex 2, there is no obvious hydrogen bonding interaction between the DMF molecules and the ligand $\mathrm{L}^{2-}$ because the $\mathrm{C}-\mathrm{H}$ bonds are not a good acceptor for H-bonding. In complex 1, apparent intrachain hydrogen bonding between the disordered methanol molecules and $\mathrm{L}^{2-}$ with the $\mathrm{O}-\mathrm{O}$ separations of $2.640 \AA$ and $2.745 \AA$, as shown in Figure S5. No intermolecular $\pi-\pi$ stacking is present in complexes 1 and 2 . 


\subsection{Magnetic Properties}

The temperature-dependent magnetic susceptibilities of complexes 1 and 2 were measured under 1000 Oe external field in the range of 2-300 K. The experimental magnetic susceptibilities were corrected for the diamagnetism of the constituent atoms (Pascal's tables). As shown in Figure 3, complexes 1 and 2 have similar magnetic susceptibility curves. The $\chi_{\mathrm{m}} T$ values of each complex remain constant above $30 \mathrm{~K}$. When the temperature was lower than $30 \mathrm{~K}$, the $\chi_{\mathrm{m}} T$ values decrease rapidly with the decrease of temperature due to the intramolecular antiferromagnetic coupling between adjacent metal ions. The data obey the Curie-Weiss law with the negative Weiss constant of $\theta=-2.71 \mathrm{~K}$ and $-4.05 \mathrm{~K}$, respectively, which further proves that the existence of antiferromagnetic interactions in complexes 1 and 2 . The room temperature $\chi_{\mathrm{m}} T$ per $\mathrm{Mn}^{\mathrm{II}} \mathrm{M}^{\mathrm{III}}{ }_{2}(\mathrm{M}=\mathrm{Fe}$ or $\mathrm{Mn})$ values were $5.317 \mathrm{~cm}^{3} \mathrm{~K} \mathrm{~mol}^{-1}$ for complex 1 and $6.588 \mathrm{~cm}^{3} \mathrm{~K} \mathrm{~mol}^{-1}$ for complex 2, are slightly higher than the theoretical value of $5.125 \mathrm{~cm}^{3} \mathrm{~K} \mathrm{~mol}^{-1}$ [two LS Fe $\mathrm{IIII}^{\mathrm{III}}$ ions $(\mathrm{S}=1 / 2)$ and one $\mathrm{HS} \mathrm{Mn}^{\mathrm{II}}$ ion $(\mathrm{S}=5 / 2)$ ] for 1 and $6.375 \mathrm{~cm}^{3} \mathrm{~K} \mathrm{~mol}^{-1}$ [two LS Mn ${ }^{\mathrm{III}}$ ions $(\mathrm{S}=1)$ and one $\mathrm{HS} \mathrm{Mn}{ }^{\mathrm{II}}$ ion $\left.(\mathrm{S}=5 / 2)\right]$ for 2 . As shown in Figure 4 , the field dependence $(0-50 \mathrm{kOe})$ of the magnetization shows that with the increase of the field, the magnetization increases gradually and reaches the maximum values of $6.088 \mathrm{~N} \beta$ and $5.749 \mathrm{~N} \beta$ at $50 \mathrm{kOe}$ for complexes 1 and 2, respectively. The experimental curves for complexes 1 and 2 lie below the Brillouin curves corresponding to non-interacting LS-S $\mathrm{S}_{\mathrm{Fe}} / \mathrm{S}_{\mathrm{Mn}}$ and $\mathrm{S}_{\mathrm{Mn}}$ spins with $g=2.0$, indicating the existence of overall antiferromagnetic coupling. The Brillouin function, $B_{\mathrm{S}}$, is $\left[\left(S+\frac{1}{2}\right) / S\right] \operatorname{coth}\left(S+\frac{1}{2}\right) \frac{g \beta H}{k T}-\frac{1}{2 S} \operatorname{coth} \frac{g \beta H}{2 k T}$ and the magnetization $M$ equals $N g \beta S B_{S}$ [21].

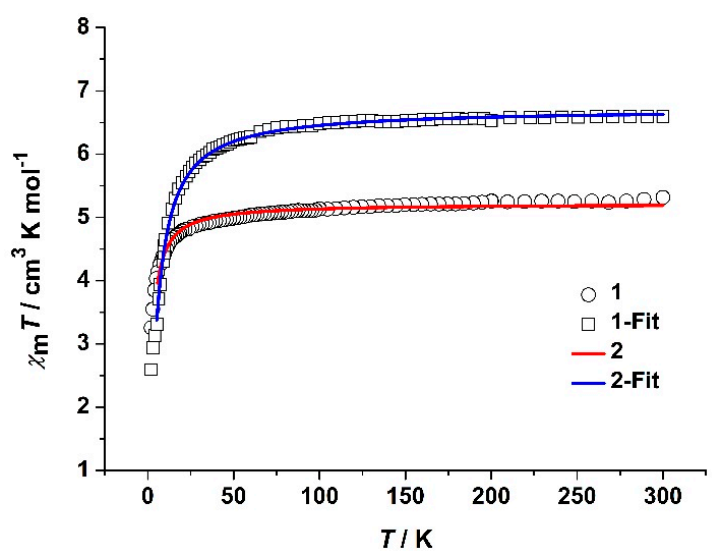

Figure 3. Variable-temperature magnetic susceptibilities for complexes 1 and 2 under a $1000 \mathrm{Oe}$ applied field.

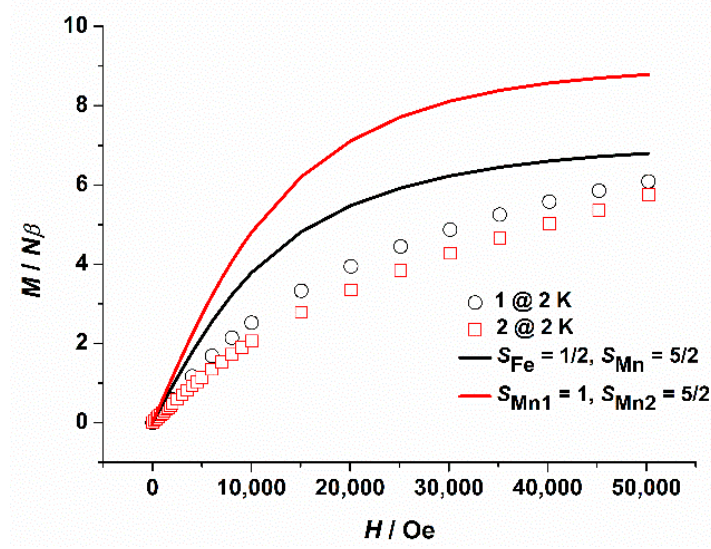

Figure 4. The field dependence of magnetization curve for complexes 1 and 2 at $2 \mathrm{~K}$. The solid lines represent the Brillouin function that corresponds to two $S_{\mathrm{Fe}}=1 / 2$ and one $S_{\mathrm{Mn}}=5 / 2$ spin states with $g=2.0$ (black) and two $S_{\mathrm{Mn} 1}=1$ and one $S_{\mathrm{Mn} 2}=5 / 2$ spin states with $g=2.0$ (red). 


\section{Discussion}

In complex 1, the low-spin octahedral Fe ${ }^{\mathrm{III}}$ ion has an electronic configuration of $\mathrm{t}_{2 \mathrm{~g}}{ }^{5}$, and there is an unpaired electron on the degenerate $\pi$-orbital of $\mathrm{d}_{\mathrm{xy}}, \mathrm{d}_{\mathrm{xz}}$, and $\mathrm{d}_{\mathrm{yz}}$. The highspin octahedral $\mathrm{Mn}^{\mathrm{II}}$ ion with the $\mathrm{t}_{2 \mathrm{~g}}{ }^{3} \mathrm{eg}_{\mathrm{g}}{ }^{2}$ configuration has three unpaired electrons on the degenerate $t_{2 g} \pi$-orbitals, as well as two unpaired electrons on the degenerate $\sigma$-orbitals $\mathrm{d}_{\mathrm{x}}{ }^{2}-\mathrm{y}{ }^{2}$ and $\mathrm{d}_{\mathrm{z}}{ }^{2}$. A similar situation occurs in the $\mathrm{t}_{2 \mathrm{~g}}{ }^{4}-\mathrm{t}_{2 \mathrm{~g}}{ }^{3} \mathrm{e}_{\mathrm{g}}{ }^{2}$ between low-spin $\mathrm{Mn}{ }^{\mathrm{III}}$ ion and high-spin $\mathrm{Mn}^{\mathrm{II}}$ ion in complex 2. According to the theory of the strict orthogonality of magnetic orbitals, the configuration of the above two sets of magnetic orbitals enables both ferromagnetic and antiferromagnetic coupling in complexes 1 and 2, and usually, the latter contribution is dominant. Thus, together with the syn-anti bridged carboxyl group that tends to transfer antiferromagnetic coupling [22], overall antiferromagnetic interaction was observed in the two complexes.

To study the strength of magnetic coupling between metal ions, it is necessary to fit the temperature-dependence magnetic susceptibility. For the $\left[\mathrm{M}^{\mathrm{III}}\right]_{2}-\mathrm{Mn}{ }^{\mathrm{II}}$ chain system in complexes 1 and 2, the magnetic susceptibility data $(5-300 \mathrm{~K})$ can be fitted by the Fisher model for uniform 1D chains with $\hat{H}=-J \sum_{i=1}^{n-1} S_{i} S_{i+1}$ [23] (Equation (1)). A rough approach similar to that previously used for 2D and quasi-2D complexes [24-26] was used on the basis of the crystal data, i.e., the 1D chain can be treated as alternating uniform $\mathrm{M}_{2} \mathrm{Mn}$ trimers (Figure 5) with the identical intra-trimeric and intrachain exchange constants $\left(J_{\mathrm{t}}=J\right)$ on the basis of the Hamiltonian $\hat{H}=-J_{\mathrm{t}} \hat{S}_{M n 1}\left(\hat{S}_{F e 1}+\hat{S}_{F e 1 A}\right)$ for complex 1 and $\hat{H}=-J_{t} \hat{S}_{M n 2}\left(\hat{S}_{M n 1}+\hat{S}_{M n 1 A}\right)$ for complex 2, respectively. The corresponding fit equations for $\mathrm{M}_{2} \mathrm{Mn}$ trimers are shown in Equations (2) and (3).

$$
\chi_{\mathrm{m}}=\frac{N g^{2} \beta^{2}}{3 k T}\left[\frac{1+u}{1-u}\right] \times S_{t}\left(S_{t}+1\right),
$$

where $u=\operatorname{coth}\left(J S_{\mathrm{t}}\left(S_{\mathrm{t}}+1\right) / k T\right)-k T / J S_{\mathrm{t}}\left(S_{\mathrm{t}}+1\right)$.

For complex 1,

$$
\begin{gathered}
\chi_{\mathrm{t}}=\frac{N g^{2} \beta^{2}}{4 k T}\left[\frac{10 x^{7}+35 x^{2}+35+84 x^{-5}}{2 x^{7}+3 x^{2}+3+4 x^{-5}}\right]=\frac{N g^{2} \beta^{2}}{3 k T} S_{t}\left(S_{t}+1\right), \\
x=\exp \left(-J_{\mathrm{t}} / k T\right) .
\end{gathered}
$$

For complex 2,

$$
\begin{gathered}
\chi_{\mathrm{t}}=\frac{N g^{2} \beta^{2}}{4 k T}\left[\frac{A}{B}\right]=\frac{N g^{2} \beta^{2}}{3 k T} S_{t}\left(S_{t}+1\right), \\
\mathrm{A}=330 \exp (10 \mathrm{~K})+168 \exp (\mathrm{K})+70 \exp (-6 \mathrm{~K})+20 \exp (-11 \mathrm{~K})+2 \exp (-14 \mathrm{~K})+ \\
168 \exp (5 \mathrm{~K})+70 \exp (-2 \mathrm{~K})+20 \exp (-7 \mathrm{~K})+70, \\
\mathrm{~B}=10 \exp (10 \mathrm{~K})+8 \exp (\mathrm{K})+6 \exp (-6 \mathrm{~K})+4 \exp (-11 \mathrm{~K})+2 \exp (-14 \mathrm{~K})+8 \exp (5 \mathrm{~K})+ \\
6 \exp (-2 \mathrm{~K})+4 \exp (-7 \mathrm{~K})+6, \\
\mathrm{~K}=J_{\mathrm{t}} / 2 k T .
\end{gathered}
$$


(1)

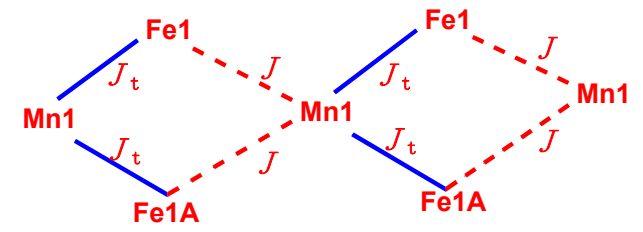

(2)

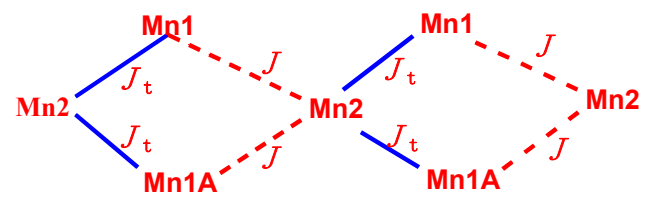

Figure 5. The $\mathrm{M}_{2} \mathrm{Mn}$-based 1D model for the fit to the magnetic susceptibility of complexes 1 and 2 $(\mathrm{M}=\mathrm{Fe}$ or $\mathrm{Mn})$.

The best-fit parameters are $g=2.017(8)$ and $J=-0.066(2) \mathrm{cm}^{-1}$ for complex 1 , and $g=2.053(4)$, $J=-0.274(2)$ for complex 2 . The calculated curves based on the above parameters are well consistent with the experimental data, and the negative $J$ values are in accordance with the prediction that the carboxyl group in syn-anti bridging mode tends to transmit antiferromagnetic coupling [22]. The absolute $J$ values are very small, precluding any possibility of a single-chain magnet for the present two complexes. The measurements on ac magnetic susceptibility show that under zero external dc field, the imaginary part of the magnetic susceptibility of complexes 1 and 2 has no signals and maintains zero.

\section{Materials and Methods}

\subsection{Materials}

All reagents were purchased from commercial sources and used without further purification. $\mathrm{H}_{2} \mathrm{~L}, \mathrm{Et}_{4} \mathrm{~N}\left[\mathrm{Fe}(\mathrm{L})_{2}\right]$, and $\mathrm{Et}_{4} \mathrm{~N}\left[\mathrm{Mn}(\mathrm{L})_{2}\right]$ were prepared according to the literature methods [16,17].

\subsection{Physical Measurements}

The C, H, and N elemental analyses were performed on a Cario Erballo elemental analyzer. IR spectra were recorded on a WQF-510A Fourier transform infrared spectrometer using KBr pellets. Magnetic susceptibility measurements were measured by a Quantum Design MPMS-XL5 SQUID magnetometer. Cyclic voltammetry measurements were tested on a CHI660E electrochemical workstation, using a platinum plate as the working electrode, platinum wire as the counter electrode, $\mathrm{Ag} / \mathrm{AgCl}$ electrode (Sat. $\mathrm{KCl})$ as the reference electrode, and $\mathrm{n}-\mathrm{Bu}_{4} \mathrm{NClO}_{4}(0.1 \mathrm{M})$ as support electrolyte in acetonitrile.

\subsection{X-ray Crystallography}

The single-crystal X-ray diffraction measurements were tested on a Rigaku R-Axis RAPID IP diffractometer by using Mo $K \alpha$ radiation $(\lambda=0.71073 \AA)$. The structures were solved by direct methods using the SHELXTL-97 program package and refined with full-matrix least squares on $F^{2}$.

\subsection{The Preparation of Complexes 1 and 2}

$\left\{\left[\mathrm{Mn}^{\mathrm{II}}(\mathrm{MeOH})_{2}\right]\left[\mathrm{Fe}^{\mathrm{III}}(\mathrm{L})_{2}\right]_{2}\right\}_{\mathrm{n}}(1)$ : A methanol solution $(10 \mathrm{~mL})$ of $\mathrm{Mn}(\mathrm{OAc})_{2} \cdot 4 \mathrm{H}_{2} \mathrm{O}(0.2 \mathrm{mmol})$ was slowly added into a methanol solution $(10 \mathrm{~mL})$ of $\mathrm{Et}_{4} \mathrm{~N}\left[\mathrm{Fe}(\mathrm{L})_{2}\right](0.2 \mathrm{mmol})$. The obtained dark purple solution was heated and stirred for about $30 \mathrm{~min}$ and then cooled, filtered, and evaporated for about 1 week to obtain dark purple block crystals. Yield: 40\%. Anal. Calcd (\%) for $\mathrm{C}_{58} \mathrm{H}_{44} \mathrm{Fe}_{2} \mathrm{MnN}_{12} \mathrm{O}_{14}: \mathrm{C}, 53.60 ; \mathrm{H}, 3.41 ; \mathrm{N}, 12.93$. Found: $\mathrm{C}, 53.59 ; \mathrm{H}, 3.49 ; \mathrm{N}, 12.70 . \mathrm{IR}\left(\mathrm{cm}^{-1}\right)$ $v\left(-\mathrm{COO}^{-}\right): 1599,1385$.

$\left\{\left[\mathrm{Mn}^{\mathrm{II}}(\mathrm{DMF})_{2}\right]\left[\mathrm{Mn}^{\mathrm{III}}(\mathrm{L})_{2}\right]_{2} \cdot \mathrm{DMF}\right\}_{n}(2):$ A DMF solution $(10 \mathrm{~mL})$ of $\mathrm{Mn}(\mathrm{OAc})_{2} \cdot 4 \mathrm{H}_{2} \mathrm{O}(0.2 \mathrm{mmol})$ was slowly added into $\mathrm{Et}_{4} \mathrm{~N}\left[\mathrm{Mn}(\mathrm{L})_{2}\right](0.2 \mathrm{mmol})$ in $\mathrm{DMF}(10 \mathrm{~mL})$. The resultant dark purple solution was diffused by ether in an $H$-tube for about 1 week to obtain red-brown block crystals. Yield: $40 \%$. Anal. Calcd (\%) for $\mathrm{C}_{65} \mathrm{H}_{57} \mathrm{Mn}_{3} \mathrm{~N}_{15} \mathrm{O}_{15}$ : C, 53.73; H, 3.95; N, 14.46. Found: C, 53.71; H, 4.07; N, 14.42. IR $\left(\mathrm{cm}^{-1}\right) \vee\left(-\mathrm{COO}^{-}\right): 1591,1382$. 


\section{Conclusions}

We used a 'complex as ligand' method to create two one-dimensional chain complexes 1 and 2 based on low-spin $\left[\mathrm{M}^{\mathrm{III}}(\mathrm{L})_{2}\right]^{-}$units $(\mathrm{M}=\mathrm{Mn}$ or $\mathrm{Fe})$. The syn-anti carboxyl bridges transmit weak antiferromagnetic coupling between adjacent $\mathrm{Mn}^{\mathrm{II}}-\mathrm{M}^{\mathrm{III}}$ ions. Complex 1 possesses a novel deflecting arrangement of $\left[\mathrm{Fe}(\mathrm{L})_{2}\right]^{-}$units and is a rare example of carboxylate-bridged heterometallic complexes [18,27]. Further work involves the construction of carboxylate- or oxime-bridged bimetallic low-dimensional magnets based on similar low-spin azo carboxylate oxime ligands.

Supplementary Materials: The following are available online at https:/ / www.mdpi.com/article/10 $.3390 /$ magnetochemistry7070105/s1, Figure S1: PXRD patterns for complexes 1 and 2 in the range of 5-50 degrees, Figure S2: (top) Side view of complex 1 along c axis; (bottom) View of the 1D skeleton of complex 1, Figure S3: Side view of complex 2 along a axis; (bottom) View of the 1D skeleton of complex 2, Figure S4: Cyclic voltammograms (scan rate $50 \mathrm{mV} \mathrm{s}^{-1}$ ) of $10-3 \mathrm{M}$ acetonitrile solutions of complexes 1 and 2 at $298 \mathrm{~K}$, Figure S5: The intrachain hydrogen bonding interaction between the disordered methanol oxygen and the carboxylate oxygen atoms of $\mathrm{L}^{2-}$ in complex 1. Table S1: The $\mathrm{r}_{0}$ values of some metal-ligand (M-L) bonds in HS metal ions, Table S2: The results calculated by SHAPE software.

Author Contributions: Conceptualization and formal analysis, M.Z. and X.C.; writing-original draft preparation, M.Z.; writing-review and editing, supervision, project administration, and funding acquisition, H.-Z.K. All authors have read and agreed to the published version of the manuscript.

Funding: This research was funded by the National Natural Science Foundation of China, grant number 21771115, 21971142, 21171103.

Institutional Review Board Statement: Not applicable.

Informed Consent Statement: Not applicable.

Data Availability Statement: Not applicable.

Conflicts of Interest: The authors declare no conflict of interest.

\section{References}

1. Sun, H.-L.; Wang, Z.-M.; Gao, S. Strategies towards single-chain magnets. Coord. Chem. Rev. 2010, 254, 1081-1100. [CrossRef]

2. Wang, S.; Ding, X.-H.; Li, Y.-H.; Huang, W. Dicyanometalate chemistry: A type of versatile building block for the construction of cyanide-bridged molecular architectures. Coord. Chem. Rev. 2012, 256, 439-464. [CrossRef]

3. Li, Y.-H.; He, W.-R.; Ding, X.-H.; Wang, S.; Cui, L.-F.; Huang, W. Cyanide-bridged assemblies constructed from capped tetracyanometalate building blocks $\left[\mathrm{MA}(\text { ligand })(\mathrm{CN})_{4}\right]^{1-/ 2-}(\mathrm{MA}=\mathrm{Fe}$ or Cr). Coord. Chem. Rev. 2012, 256, 2795-2815. [CrossRef]

4. Chen, X.; Wu, S.-Q.; Cui, A.-L.; Kou, H.-Z. A cyano-bridged single-chain magnet featuring alternate high- and low-spin manganese(III) porphyrins. Chem. Commun. 2014, 50, 2120-2122. [CrossRef]

5. Zhang, Y.-Z.; Zhao, H.-H.; Funck, E.; Dunbar, K.R. A Single-Chain Magnet Tape Based on Hexacyanomanganate(III). Angezw. Chem. Int. Ed. 2015, 54, 5583-5587. [CrossRef]

6. Palii, A.; Ostrovsky, S.M.; Klokishner, S.I.; Tsukerblat, B.S.; Dunbar, K.R. Highly Anisotropic Orbitally Dependent Superexchange in Cyano-Bridged Clusters Containing Mn(III) and Mn(II) Ions. ChemPhysChem 2006, 7, 871-879. [CrossRef]

7. Kahn, O. Molecular Magnets; Wiley-VCH: NewYork, NY, USA, 1993; pp. 175-181.

8. Miyasaka, H.; Madanbashi, T.; Saitoh, A.; Motokawa, N.; Ishikawa, R.; Yamashita, M.; Bahr, S.; Wernsdorfer, W.; Clerac, R. Cyano-Bridged $\mathrm{Mn}^{\mathrm{III}}-\mathrm{M}^{\mathrm{III}}$ Single-Chain Magnets with $\mathrm{M}^{\mathrm{III}}=\mathrm{Co}^{\mathrm{III}}, \mathrm{Fe}^{\mathrm{III}}, \mathrm{Mn}^{\mathrm{III}}$, and $\mathrm{Cr}^{\mathrm{III}}$. Chem. Eur. J. 2012, 18, 3942-3954. [CrossRef] [PubMed]

9. Buades, A.B.; Arderiu, V.S.; Maxwell, L.; Amoza, M.; Choquesillo-Lazarte, D.; Aliaga-Alcalde, N.; Vinas, C.; Teixidor, F.; Ruiz, E. Slow-spin relaxation of a low-spin $S=1 / 2 \mathrm{Fe}^{\mathrm{III}}$ carborane complex. Chem. Commun. 2019, 55, 3825-3828. [CrossRef] [PubMed]

10. Cirera, J.; Ruiz, E.; Alvarez, S.; Neese, F.; Kortus, J. How to Build Molecules with Large Magnetic Anisotropy. Chem. Eur. J. 2009, 15, 4078-4087. [CrossRef] [PubMed]

11. Gheorghe, R.; Madalan, A.M.; Costes, J.-P.; Wernsdorfer, W.; Andruh, M. A heterotrimetallic 3d-3d'-4f single chain magnet constructed from anisotropic high-spin 3d-4f nodes and paramagnetic spacers. Dalton Trans. 2010, 39, 4734-4736. [CrossRef]

12. Dhers, S.; Feltham, H.L.C.; Rouzieres, M.; Clerac, R.; Brooker, S. Discrete versus Chain Assembly: Hexacyanometallate Linkers and Macrocyclic \{3d-4f\} Single-Molecule Magnet Building Blocks. Inorg. Chem. 2019, 58, 5543-5554. [CrossRef] [PubMed]

13. Pinkowicz, D.; Southerland, H.I.; Avendano, C.; Prosvirin, A.; Sanders, C.; Wernsdorfer, W.; Pedersen, K.S.; Dreiser, J.; Clerac, R.; Nehrkorn, J.; et al. Cyanide Single-Molecule Magnets Exhibiting Solvent Dependent Reversible “On" and "Off" Exchange Bias Behavior. J. Am. Chem. Soc. 2015, 137, 14406-14422. [CrossRef] 
14. Bai, Y.-L.; Tao, J.; Wernsdorfer, W.; Sato, O.; Huang, R.-B.; Zheng, L.-S. Coexistence of Magnetization Relaxation and Dielectric Relaxation in a Single-Chain Magnet. J. Am. Chem. Soc. 2006, 128, 16428-16429. [CrossRef] [PubMed]

15. Kar, P.; Biswas, R.; Drew, M.G.B.; Ida, Y.; Ishida, T.; Ghosh, A. Structure and magnetic properties of an unprecedented syn-anti $\mu$-nitrito-1 $\mathrm{\kappa O}: 2 \mathrm{k} \mathrm{O}^{\prime}$ bridged $\mathrm{Mn}(\mathrm{III})$-salen complex and its isoelectronic and isostructural formate analogue. Dalton Trans. 2011, 40, 3295-3304. [CrossRef] [PubMed]

16. Karmakar, S.; Chakravorty, A. Carboxyl-Bonded Low-Spin Iron(III). Chemistry of a Family of Coordination Type cis-FeN4O2. Inorg. Chem. 1996, 35, 1935-1939.

17. Ganguly, S.; Karmakar, S.; Chakravorty, A. First Examples of Carboxyl-Bonded Low-Spin Manganese(III) Complexes. Inorg. Chem. 1997, 36, 116-118. [CrossRef]

18. Chen, X.; Cui, A.-L.; Liu, C.-M.; Kou, H.-Z. Synthesis, structures, and magnetic properties of carboxylate-bridged trinuclear complexes based on low-spin manganese(III)/iron(III) building blocks. Transit. Met. Chem. 2013, 38, 683-688. [CrossRef]

19. Kou, H.Z.; Zhang, Y.D.; Cui, A.L. Carboxylate-bridged helical chains based on an azo carboxylate oximate ligand. Sci. China Chem. 2012, 55, 1042-1046. [CrossRef]

20. Llunell, M.; Casanova, D.; Cirera, J.; Alemany, P.; Alvarez, S. SHAPE, version 2.1; University of Barcelona: Barcelona, Spain, 2013.

21. Carlin, R.L. Magnetochemistry; Springer: Berlin/Heidelberg, Germany, 1986; pp. 14-18.

22. Pei, Y.; Nakatani, K.; Kahn, O.; Sletten, J.; Renard, J.P. Magnetism of alternating bimetallic chains: Application to triaqua(oxamidoN-benzoato-N-propionato)coppermanganese monohydrate. Inorg. Chem. 1989, 28, 3170-3175. [CrossRef]

23. Fisher, M.E. Magnetism in One-Dimensional Systems-The Heisenberg Model for Infinite Spin. Am. J. Phys. 1964, 32, 343-346. [CrossRef]

24. Chiari, B.; Cinti, A.; Piovesana, O.; Zanazzi, P.F. Exchange Interactions in the Bimetallic Chain Compound $\mathrm{Cu}_{(\mathrm{e}}$ ethylenediamine) ${ }_{2} \mathrm{MnCl}_{4}$. Inorg. Chem. 1995, 34, 2652-2657. [CrossRef]

25. Ni, Z.-H.; Kou, H.-Z.; Zhao, Y.-H.; Zheng, L.; Wang, R.-J.; Cui, A.-L. Fe(bpb)(CN $\left.)_{2}\right]^{-}$as a Versatile Building Block for the Design of Novel Low-Dimensional Heterobimetallic Systems: Synthesis, Crystal Structures, and Magnetic Properties of Cyano-Bridged $\mathrm{Fe}^{\mathrm{III}}-\mathrm{Ni}^{\mathrm{II}}$ Complexes [(bpb) ${ }^{2-}=1,2-$ Bis(pyridine-2-carboxamido)benzenate]. Inorg. Chem. 2005, 44, 2050-2059.

26. Li, L.; Liao, D.; Jiang, Z.; Yan, S. A 3-D Polymer, Mn(NITpPy $)_{2}(\mathrm{tp})\left(\mathrm{H}_{2} \mathrm{O}\right)_{2}$ : Crystal Structure and Magnetic Properties. Inorg. Chem. 2002, 41, 421-424. [CrossRef] [PubMed]

27. Cheng, A.-L.; Liu, N.; Zhang, J.-Y.; Gao, E.-Q. Assembling the Cage-Based Metal-Organic Network from a Cubic Metalloligand. Inorg. Chem. 2007, 46, 1034-1035. [CrossRef] [PubMed] 